\title{
Perbuatan Melawan Hukum Dalam Sengketa Tanah Lapangan Bola Kab. Lampung Selatan (Studi Putusan Nomor: 17/pdt.g/2020/PN Kla)
}

\author{
I Wayan Nanda D ${ }^{1}$, Zainab Ompu Jainah ${ }^{2}$, Anggalana ${ }^{3}$ \\ 1,2,3Fakultas Hukum Universitas Bandar Lampung, Indonesia \\ Email konfirmasi: judaspriest1213@gmail.com
}

\begin{abstract}
ABSTRAK
Penelitian ini bertujuan untuk menganalisis perbuatan melawan hukum dalam sengketa tanah lapangan bola di Dusun Jatisari Desa Jatimulyo Kecamatan Jati Agung Kabupaten Lampung Selatan, dimana berdasarkan Putusan Nomor: 17/Pdt.G/2020/PN Kla disebutkan bahwa mengabulkan gugatan Penggugat (M. Basyarruddin) untuk seluruhnya, menyatakan bahwa Para Tergugat (Sumarjo, Sugiyanto, Sarjiyo, Djumino dan Jumadi) telah melakukan perbuatan melawan hukum, menyatakan sah secara hukum atas objek tanah sengketa dimaksud. Metode penelitian menggunakan pendekatan yuridis normatif dan empiris. Sumber data normatif dan empiris. Pengumpulan data melalui penelitian kepustakaan (library research) dan penelitian lapangan (field research). Analisis data yang digunakan adalah yuridis kualitatif. Hasil penelitian dan pembahasan menunjukkan bahwa faktor penyebab terjadinya perbuatan melawan hukum dalam sengketa tanah lapangan bola di Dusun Jatisari Desa Jatimulyo Kecamatan Jati Agung Kabupaten Lampung Selatan berdasarkan Putusan Nomor 17/Pdt.G/2020/PN Kla adalah karena adanya kelalaian (culpa) atau karena kesengajaan (dolus) yang dilakukan Kecamatan Jati Agung dalam pembuatan surat tidak dalam sengketa atas tanah objek perkara sehingga Pihak Tergugat mendaftarkan tanah objek perkara ke kantor Badan Pertanahan Kabupaten Lampung Selatan. Oleh karena perbuatan karena kelalaian atau kesengajaan akan menghasilkan sertifikat yang cacat hukum atau adanya sertifikat ganda yang termasuk dalam kategori perbuatan melawan hukum.
\end{abstract}

Kata Kunci: Perbuatan Melawan Hukum; Sengketa Tanah; Lapangan Bola.

\section{Pendahuluan}

Negara Indonesia merupakan negara yang berdasarkan atas hukum, sebagaimana yang diatur dalam Pasal 1 ayat (3) Jo. Pasal 27 ayat (1) Undang-Undang Dasar Republik Indonesia Tahun 1945 yaitu segala warga negara bersamaan kedudukannya di dalam hukum dan pemerintahan dan wajib menjunjung hukum dan pemerintahan itu dengan tidak ada kecualinya Jo. Pasal 28 D ayat (1) Undang- 
Undang Dasar Republik Indonesia Tahun 1945 yaitu setiap orang berhak atas pengakuan, jaminan, perlindungan dan kepastian hukum yang adil serta perlakuan yang sama dihadapan hukum.

Maka setiap tindakan yang bertentangan atas Pancasila dan Undang-Undang Dasar 1945 Negara Republik Indonesia (selanjutnya disebut UUD 1945) sebagai dasar hukum yang paling hakiki disamping produk-produk hukum lainnya. Negara hukum adalah konsep yang berparadigma bahwa Negara dan alat kekuasaannya (pemerintah) tak dibenarkan bertindak atas kekuasaannya belaka, melainkan harus ditumpukan pada dasar kebenaran hukum yang telah dipositifkan ialah undang-undang yang pada gilirannya berdiri tegak diatas kebenaran hukum undang-undang yang paling dasar, ialah Undang-Undang Dasar (Budiarjo, 2009: 52).

Perbuatan melawan hukum merupakan hal yang penting dalam bidang hukum perdata. Penerapan konsepsi perbuatan melawan hukum sering kali di persamakan dengan konsepsi perbuatan ingkar janji (wanprestasi). Padahal keduanya merupakan konsepsi yang sangat berbeda satu dengan lainnya, walaupun keduanya bersumber dari perikatan, yaitu konpsesi wanprestasi berasal dari perikatan yang lahir dari perjanjian dan konsepsi perbuatan melawan hukum berasal dari perikatan yang lahir dari undang-undang.

Menurut asas verbintenissenrecht, manusia yang satu terlepas dari manusia lain. Dalam masyarakat ini manusia yang satu menghormati manusia lain karena manusia itu pribadi. Perbuatan yang mengganggu keseimbangan ini disebut dengan perbuatan melawan hukum (onrechtmatige daad). Tertib masyarakatlah yang menentukan perbuatan mana merupakan onrechtmatige daad, juga menentukan batas sempit tidaknya pengertian dari onrechtmatige daad. Pada prinsipnya onrechtmatige daad ada jika orang berbuat atau tidak berbuat yang melanggar hak orang lain atau bertentangan dengan kewajiban hukum dari orang yang berbuat itu sendiri atau pula bertentangan dengan tata susila atau sikap kehati-hatian sebagaimana sepatutnya dalam pergaulan masyarakat ini terhadap diri dan orang lain (Budiono, 2010: 45).

Perbuatan onrechtmatige daad telah mengakibatkan pelanggaran terhadap hak orang lain tentunya ada konskuensi yang harus ditanggug akibat perbuatan onrechtmatige daad tersebut. Dalam Pasal 1365 KUHPerdata, dinyatakan bahwa "Setiap perbuatan melawan hukum, yang oleh karenanya menimbulkan kerugian pada orang lain, mewajibkan orang yang karena kesalahannya menyebabkan kerugian itu mengganti kerugian". Berdasarkan ketentuan pasal tersebut, maka kesalahan akibat perbuatan melawan hukum menimbulkan kewajiban untuk memberikan ganti rugi akibat perbuatan tersebut (Rusli, 2012: 29).

Pada pergaulan hidup bermasyarakat manusia adalah sentral, manusia adalah penggerak kehidupan masyarakat karena manusia itu adalah pendukung hak dan kewajiban. Dengan demikian, hukum perdata material pertama kali menentukan 
dan mengatur siapakah yang dimaksud dengan orang sebagai pendukung hak dan kewajiban itu (A. Kadir, 2000: 3-4).

Salah satu contoh perbuatan melawan hukum adalah menghuni tanah dan bangunan secara tidak sah tanpa seijin pemilik yang menimbulkan sengketa. Tanah sebagai barang tidak bergerak merupakan kebutuhan mendasar dalam kehidupan masyarakat dimana tanah memiliki peran dan fungsi yang sangat penting dalamkehidupan masyarakat sehari-hari. Keberadaan tanah sendiri dari hari kehari dirasa semakin sempit mengingat kebutuhan masyarakat dan pemerintah terhadap tanah semakin meningkatbaik tanah sebagai tempat tinggal maupun untuk tempat usaha bagi masyarakat. Bagi pemerintah, tanah juga diperlukan guna pembangunan sarana yang akan bermanfaat bagi kehidupan masyarakat.

Tanah merupakan harta yang sangat bernilai dimana setiap tahunnya selalu memiliki nilai jual yang tidak pernah surut. Tanah memiliki peran yang sangat penting dalam setiap kehidupan dan kegiatan usaha manusia. Eksistensi tanah dalam kehidupan manusia mempunyai arti dan sekaligus memiliki fungsi ganda, yaitu sebagai social asset dan capital asset. Sebagai social asset tanah merupakan sarana pengikat kesatuan sosial di kalangan masyarakat untuk hidup dan kehidupan, sedangkan capital asset tanah merupakan faktor modal dalam pembangunan dan telah tumbuh sebagai benda ekonomi yang sangat penting sekaligus sebagai bahan perniagaan dan objek spekulasi. Sengketa tanah merupakan perselisihan yang terjadi antara dua pihak atau lebih yang merasa atau dirugikan pihak-pihak tersebut untuk penggunaan dan penguasaan hak atas tanahnya, yang diselesaikan melalui musyawarah atau melalui pengadilan.

Pertimbangan Hakim dalam menjatuhkan putusan sangat penting, putusan Hakim diyakini mengandung keadilan dan mengandung kepastian hukum, di samping itu juga harusmengandung manfaat bagi para pihak yang bersangkutan. Pengambilan keputusan sangatdiperlukan oleh hakim atas sengketa yang diperiksa dan diadilinya. Hakim harus dapatmengolah dan memproses datadata yang diperoleh selama proses persidangan, baik daribukti surat, saksi, persangkaan, pengakuan maupun sumpah yang terungkap dalampersidangan. Sehingga keputusan yang akan dijatuhkan dapat didasari oleh rasa tanggungjawab, keadilan, kebijaksanaan, profesionalisme dan bersifat obyektif.

Hakim memegang peranan penting dari awal sampai akhir pemeriksaan di Pengadilan. Berdasarkan Pasal 119 HIR atau 143 RBg Hakim berwenang untuk memberikan petunjukkepada pihak yang mengajukan gugatannya ke Pengadilan dengan maksud agar sengketa tersebut menjadi jelas duduk sengketanya dan memudahkan Hakim memeriksa sengketa itu. Dalam pemeriksaan sengketa, Hakim betul-betul harus bersikap bebas dan tidak memihaksiapapun. Di dalam persidangan, Hakim juga harus mendengar keterangan kedua belah pihakdengan pembuktian masing-masing sehingga Hakim dapat menemukan kebenaran yang 
sesungguhnya.Pertimbangan Hakim sangat dibutuhkan dalam menjatuhkan sebuah putusan diharapkan dapat menjadi solusi atas sebuah sengketa antara para pihak yang bersangkutan. Putusan Hakim diyakini mengandung keadilan (ex aequo et bono) dan mengandung kepastian hukum, di samping itu juga harus mengandung manfaat bagi para pihak yang bersangkutan. Hak atas Tanah di Indonesia diakui oleh UUPA yang diwujudkan dalam bentuk sertifikat hak atas tanah sebagai alat pembuktian yang kuat yang ditindaklanjuti oleh Peraturan Pemerintah Nomor 10 Tahun 1961 yang kini telah dicabut dan ditegaskan kembali dalam Peraturan Pemerintah Nomor 24 Tahun 1997 tentang Pendaftaran Tanah.

Salah satu bentuk perbuatan melawan hukum adalah dalam sengketa tanah lapangan bola di Dusun Jatisari Desa Jatimulyo Kecamatan Jati Agung Kabupaten Lampung Selatan, dimana berdasarkan Putusan Nomor: 17/Pdt.G/2020/PN Kla disebutkan bahwa mengabulkan gugatan Penggugat (M. Basyarruddin) untuk seluruhnya, menyatakan bahwa Para Tergugat (Sumarjo, Sugiyanto, Sarjiyo, Djumino dan Jumadi) telah melakukan perbuatan melawan hukum, menyatakan sah secara hukum bahwa objek tanah sengketa sebidang tanah yang terletak di Dusun V Jati Sari Desa Jati Mulyo Kecamatan Tanjung Bintang Kabupaten Lampung Selatan dengan Luas kurang lebih $73.200 \mathrm{M}^{2}$ (tujuh puluh tiga ribu dua ratus meter persegi) adalah sah milik Penggugat, menghukum Para Tergugat untuk mengganti kerugian kepada Penggugat dengan Rincian Sebagai Berikut:

a. Tergugat I (Sumarjo) mengganti kerugian kepada Penggugat sebesar Rp. 3.300.000.000,- (tiga milyar tiga ratus juta rupiah).

b. Tergugat II (Sugiyanto) mengganti kerugian kepada Penggugat sebesar Rp. 9.150.000.000,- (Sembilan milyar seratus lima puluh juta rupiah).

c. Tergugat III (Sarjiyo) mengganti kerugian kepada Penggugat sebesar Rp. 7.500.000.000,- (tujuh milyar lima ratus juta rupiah).

d. Bahwa Tergugat IV (Djumino) mengganti kerugian kepada Penggugat sebesar Rp. 7.500.000.000,- (tujuh milyar lima ratus juta rupiah).

e. Tergugat V (Jumadi) mengganti kerugian kepada Penggugat sebesar Rp. 9.150.000.000,- (Sembilan milyar seratus lima puluh juta rupiah).

f. Total Ganti kerugian yang harus dibayarkanoleh Para Tergugat kepada Penggugat adalah sebesar Rp. 36.600.000.000,- (tiga puluh enam milyar enam ratus juta rupiah).

Menghukum para tergugat untuk membayar ganti kerugian Immateril sebesar Rp. 50.000.000.000,- (lima puluh milyar rupiah). Menghukum Para Tergugat untuk membayar uang paksa (dwangsom) kepada Penggugat sebesar Rp.1.000.000,- (satu juta rupiah) setiap hari keterlambatan pemenuhan isi putusan sejak perkara ini memperoleh kekuatan hukum tetap (inkracht). Menghukum para tergugat dan turut tergugat untuk patuh dan melaksanakan putusan ini. Menetapkan putusan ini dilaksanakan tertebih dahulu walaupun diadakan upaya Hukum 
Banding (uitvoerbaar bij voorraad). Menetapkan seluruh biaya perkara yang timbul dalam perkara ini di bebankan oleh Tergugat.

\section{METODE PENELITIAN}

Penulisan ini menggunakan penelitian hukum normatif atau perpustakaan yang merupakan penelitian yang mengkaji studi dokumen. Penelitian jenis normatif ini menggunakan analisis kualitatif yakni dengan menjelaskan data yang ada dengan kata-kata atau pernyataan bukan dengan angka-angka. Dalam penelitian ini penulis memperoleh sumber data dari bahan sumber data primer dan sumber data sekunder. Teknik pengambilan data ini dengan membaca buku-buku/ jurnal maupun situs internet yang berkaitan dengan tema penulisan ini. Analisis data yang digunakan penelitian ini adalah teknik analisis kualitatif.

\section{PEMBAHASAN}

\section{Faktor Penyebab Terjadinya Perbuatan Melawan Hukum dalam Sengketa} Tanah Lapangan Bola (Studi Putusan Nomor 17/Pdt.G/2020/PN Kla)

Sengketa atas tanah terjadi karena adanya dua kepentingan antara pemilik tanah yang sama-sama mengaku memiliki tanah tersebut, karena dijual, ditukar atau dijadikan hak tanggungan dan sebagainya. Sengketa pertanahan juga terjadi dalam pemberian ganti rugi tanah yang dibebaskan oleh pemerintah guna pembangunan untuk kepentingan umum, seperti halnya untuk pembuatan waduk, jalan, pasar, pelabuhan laut maupun udara, terminal bus dan lain-lain.

Tipologi kasus pertanahan merupakan jenis sengketa, konflik, atau perkara pertanahan yang disampaikan atau diadukan dan ditangani oleh Badan Pertanahan Nasional, yang merupakan perbuatan melawan hukum sehingga terjadi adanya persengketaan atas tanah akibat adanya perbuatan melawan hukum yang secara garis besar dikelompokkan menjadi penguasaan tanah tanpa hak, sengketa batas, sengketa waris, jual berkali-kali, sertipikat ganda, sertipikat pengganti, akta jual beli palsu, kekeliruan penunjukan batas, tumpang tindih dan putusan pengadilan.

Berdasarkan Putusan Nomor: 17/Pdt.G/2020/PN Kla disebutkan bahwa mengabulkan gugatan Penggugat (M. Basyarruddin) untuk seluruhnya, menyatakan bahwa Para Tergugat (Sumarjo, Sugiyanto, Sarjiyo, Djumino dan Jumadi) telah melakukan perbuatan melawan hukum, menyatakan sah secara hukum bahwa objek tanah sengketa sebidang tanah yang terletak di Dusun V Jati Sari Desa Jati Mulyo Kecamatan Tanjung Bintang Kabupaten Lampung Selatan dengan Luas kurang lebih $73.200 \mathrm{M}^{2}$ (tujuh puluh tiga ribu dua ratus meter persegi) adalah sah milik Penggugat.

Menghukum Para Tergugat untuk mengganti kerugian kepada Penggugat dengan Rincian Sebagai Berikut: 
a. Tergugat I (Sumarjo) mengganti kerugian kepada Penggugat sebesar Rp. 3.300.000.000,- (tiga milyar tiga ratus juta rupiah).

b. Tergugat II (Sugiyanto) mengganti kerugian kepada Penggugat sebesar Rp. 9.150.000.000,- (Sembilan milyar seratus lima puluh juta rupiah).

c. Tergugat III (Sarjiyo) mengganti kerugian kepada Penggugat sebesar Rp. 7.500.000.000,- (tujuh milyar lima ratus juta rupiah).

d. Bahwa Tergugat IV (Djumino) mengganti kerugian kepada Penggugat sebesar Rp. 7.500.000.000,- (tujuh milyar lima ratus juta rupiah).

e. Tergugat V (Jumadi) mengganti kerugian kepada Penggugat sebesar Rp. 9.150.000.000,- (Sembilan milyar seratus lima puluh juta rupiah).

f. Total Ganti kerugian yang harus dibayarkanoleh Para Tergugat kepada Penggugat adalah sebesar Rp. 36.600.000.000,- (tiga puluh enam milyar enam ratus juta rupiah).

Menghukum para tergugat untuk membayar ganti kerugian Immateril sebesar Rp. 50.000.000.000,- (lima puluh milyar rupiah). Menghukum Para Tergugat untuk membayar uang paksa (dwangsom) kepada Penggugat sebesar Rp.1.000.000,- (satu juta rupiah) setiap hari keterlambatan pemenuhan isi putusan sejak perkara ini memperoleh kekuatan hukum tetap (inkracht). Menghukum para tergugat dan turut tergugat untuk patuh dan melaksanakan putusan ini. Menetapkan putusan ini dilaksanakan tertebih dahulu walaupun diadakan upaya Hukum Banding (uitvoerbaar bij voorraad). Menetapkan seluruh biaya perkara yang timbul dalam perkara ini di bebankan oleh Tergugat.

Hasil wawancara dengan Chandra Revolisa selaku Hakim Pengadilan Negeri Kalianda menyatakan bahwa adanya kelalaian (culpa) atau karena kesengajaan (dolus) yang dilakukan Kecamatan Jati Agung dalam pembuatan surat tidak dalam sengketa atas tanah objek perkara sehingga Pihak Tergugat mendaftarkan tanah objek perkara ke kantor Badan Pertanahan Kabupaten Lampung Selatan. Oleh karena perbuatan karena kelalaian atau kesengajaan akan menghasilkan sertifikat yang cacat hukum.

Hasil wawancara dengan Eka Maisanti selaku Panitera Pengadilan Negeri Kalianda menyatakan bahwa kesalahan atas subjek hukum dalam sertifikat maupun kesalahan atas objek hukum dalam sertifikat sering terjadi dalam pelaksanaaan pendaftaran tanah. Kesalahan dalam pembuatan sertifikat bisa saja karena adanya unsur-unsur penipuan (bedrog), kesesatan (dwaling) dan atau paksaan (dwang) dalam pembuatan data fisik maupun data yuridis yang dibukukan dalam buku tanah. Sertifikat hak atas tanah yang diterbitkan dapat batal demi hukum. Sedangkan bagi subjek yang melakukan hal tersebut dapat dikatakan telah melakukan perbuatan melawan hukum (onrecht matigedaad). Termasuk perbuatan tersebut dilakukan oleh Kantor Pertanahan Kabupaten Lampung Selatan karena kurang teliti dalam pengecekan pengukuran tanah, dan pembuatan surat palsu yang dilakukan 
Kecamatan Jati Agung, maka perbuatan tersebut dapat dikategorikan penyalahgunaan kewenangan dari Pejabat Tata Usaha Negara.

Terdapat dua hal penting dalam sengketa pertanahan yaitu sengketa pertanahan secara umum dan sengketa pertanahan secara khusus, sebagaimana terdapat dalam Keputusan BPN RI nomor 34 Tahun 2007 tentang Petunjuk Teknis Penanganan Dan Penyelesaian Masalah Pertanahan ada dua faktor utama yaitu:

1. Faktor hukum

a. Regulasi kurang memadai;

Regulasi di bidang pertanahan belum seutuhnya mengacu pada nilai-nilai dasar Pancasila dan filosofi Pasal 33 UUD 1945 tentang moral, keadilan, hak asasi, dan kesejahteraan. Disisi lain penegakan hukum kerap kali berhenti pada mekanisme formal dari aturan hukum dan mengabaikan nilai-nilai substansinya.

b. Tumpang tindih peradilan;

Saat ini terdapat tiga lembaga peradilan yang dapat menangani suatu sengketa pertanahan yaitu peradilan perdata, peradilan pidana, serta Peradilan Tata Usaha Negara (PTUN). Dalam suatu sengketa tertentu, salah satu pihak yang menang secara perdata belum tentu menang secara pidana. Selain itu, sumber daya aparatur agrarian juga merupakan hal yang memicu timbulnya sengketa.

c. Penyelesaian dan birokrasi berbelit-belit

Penyelesaian perkara lewat pengadilan di Indonesia melelahkan, biaya yang tinggi dan waktu penyelesaian yang lama apalagi bila terjebak dengan mafia peradilan, maka keadilan tidak berpihak pada yang benar. Hal ini tentunya tidak sesuai lagi dengan prinsip peradilan kita yang sederhana, cepat, dan berbiaya murah, karena kondisinya saat ini dalam berurusan dengan pengadilan tidaklah sederhana, birokrasi pengadilan yang berbelit-belit dan lama serta biaya yang mahal.

d. Tumpang tindih peraturan

UUPA sebagai induk dari peraaturan sumber daya agrarian lainnya khususnya tanah, namun dalam berjalan waktu dibuatlah peraturan perundang-undangan yang berkaitan drngan sumber daya agrarian tetapi tidak menenmpatkan UUPA sebagai undang-undang induknya, bahkan justru menempatkan UUPA sejajar dengan undang-undang agrarian. Struktur hukum agrarian menjadi tumpang tindih. UUPA yang awalnya merupakan payung hukum bagi kebijakan pertanahan di Indonesia, menjadi tidak berfungsi dan bahkan secara substansial terdapat pertentangan dengan diterbitkannya peraturan-peraturan perundangan sektoral.

2. Faktor non hukum 
a. Tumpang tindih penggunaan tanah

Pertumbuhan penduduk yang cepat mengakibatkan jumlah penduduk bertambah, sedangkan produksi pangan berkurang akibat berubah fungsinya tanah pertanian. Juga pemerintah yang terus-menerus menyelenggarakan proyek pembangunan. Tidak dapat dihindarkan jika sebidang tanah yang sama memiliki ataupun timbul kepentingaan yang berbeda. Itulah mengapa pertumbuhan sengketa tanah yang terus menerus meningkat.

b. Nilai ekonomis tanah yang tinggi

Sejak masa Orde Baru, nilai ekonomis tanah semakin tinggi. Hal ni terkait dengan politik peningkatan pertumbuhan ekonomi yang dicanangkan pemerintah dengan menitikberatkan pada pembangunan. Pemerintah orde baru menetapkan kebijakan berupa tanah sebagai bagian dari sumber daya agraria tidak lagi menjadi sumber produksi atau tanah tidak lagi untuk kemakmuran rakyat, melainkan tanah sebagai aset pembangunan demi mengejar pertumbuhan ekonomi yang bahkan kebijakan itu sangat merugikan rakyat. Fungsi sosial tanahpun dikesampingkan karena semuanya berorientasi pada bisnis. Kebijakan pemerintah orde baru dapat menimbulkan sengketa penguasaan sumber daya agrarian antara pemilik tanah dalam hal ini rakyat dengan para pemilik modal yang difasilitasi pemerintah.

c. Kesadaran masyarakat meningkat

Perkembangan global serta peningkatan perkembangan ilmu pengetahuan dan teknologi berpengaruh pada peningkatan kesadaran masyarakat. Pola pikir masyarakat terhadap penguasaan tanahpun ikut berubah. Terkait dengan tanah sebagai aset pembangunan, maka muncul perubahan pola pikir masyarakat terhadap penguasaan tanah, yaitu tidak lagi menempatkan tanah sebagai sumber produksi akan tetapi menjadikan tanah sebagai sarana untuk investasi atau komoditas ekonomi. Jika sebelumnya pemberian ganti rugi dalam pengadaan tanah untuk pembangunan kepentingan hanya diberikan "seadanya" bahkan diserahkan dengan sukarela dan cuma-cuma, pelanpelan berubah mengacuh pada NJOP (nilai jual objek pajak). Belakangan masyarakat menuntut adanya penberian ganti rugi berdasarkan harga pasar bahkan lebih dari pada itu dengan menuntut pemberian kompensasi berupa pemukiman kembali yang lengkap dengan fasilitas yang kurang lebih sama dengan tempat asal mereka yang dijadikan areal pembangunan.

d. Tanah tetap penduduk bertambah

Pertumbuhan penduduk yang sangat cepat, baik lewat kelahiran maupun migrasi serta urbanisasi, sementara luas lahan yang relatif tetap, menjadikan tanah sebagai komoditas ekonomi yang nilainya sangat tinggi, sehingga setiap jengkal tanah dipertahankan mati-matian.

e. Kemiskinan 
Kemiskinan merupakan masalah kompleks yang dipengaruhi oleh berbagai faktor yang berkaitan. Dalam memenuhi kebutuhan pertanahan, masyarakat miskin menghadapi masalah ketimpangan struktur penguasaan dan pemilikan tanah, serta ketidakpastian dalam penguasaan dan pemilikan lahan pertanian. Padahal kehidupan rumah tangga petani sangat dipengaruhi oleh aksesnya terhadap tanah dan kemampuan mobilisasi anggota keluarganya untuk bekerja di atas tanah pertanian. Oleh sebab itu, meningkatnya petani gurem mencerminkan kemiskinan di perdesaan. Masalah tersebut bertambah buruk dengan struktur penguasaan lahan yang timpang karena sebagian besar petani gurem tidak secara formal menguasai lahan sebagai hak milik, dan kalaupun mereka memiliki tanah, perlindungan terhadap hak atas tanah mereka tidak cukup kuat karena tanah tersebut seringkali tidak bersertifikat.

Secara garis besar dapat ditarik beberapa hal yang menyebabkan timbulnya sengketa pertanahan dan sertifikat ganda yaitu sebagai berikut:

a. Kurangnya transparansi informasi mengenai kepemilikan tanah.

b. Nilai tanah yang ekonomis dan tanah yang dijadikan masyarakat sebagai simbol eksistensi sosial bermasyarakat, sehingga setiap orang menggunakan segala cara untuk mempertahankannya.

c. Lemahnya regulasi padahal sengketa pertanahan bersifat multidimensional.

d. Tumpang tindihnya keputusan-keputusan yang dikeluarkan lembagalembaga negara yang berkepentingan mengenai kepemilikan hak atas tanah.

e. Tafsiran di kalangan masyarakat yang salah mengartikan mana tanah adat atau memiliki hak ulayat dan mana yang merupakan tanah bukan milik adat atau tanah negara.

f. Permasalahan land reform yang sampai sekarang belum bisa terpecahkan

g. Serta adanya bencana alam yang menyebabkan rusaknya tanda bukti kepemilikan hak atas tanah dan bergesernya tanah setelah bencana.

h. Dan yang paling kompleks adalah tidak dimanfaatkannya peta pendaftaran tanah dan sistem komputerisasi yang belum modern.

i. Bahkan ketidakjujuran aparat desa dan pemohohon dalam hal ini pemilik lahan dalam memberikan informasi kepada BPN merupakan faktor utama.

Berdasarkan uraian di atas, maka dapat dianalisis bahwa faktor penyebab terjadinya perbuatan melawan hukum dalam sengketa tanah lapangan bola di Dusun Jatisari Desa Jatimulyo Kecamatan Jati Agung Kabupaten Lampung Selatan berdasarkan Putusan Nomor 17/Pdt.G/2020/PN Kla adalah karena adanya kelalaian (culpa) atau karena kesengajaan (dolus) yang dilakukan Kecamatan Jati Agung dalam pembuatan surat tidak dalam sengketa atas tanah objek perkara sehingga Pihak Tergugat mendaftarkan tanah objek perkara ke kantor Badan Pertanahan Kabupaten Lampung Selatan. Oleh karena perbuatan karena kelalaian 
atau kesengajaan akan menghasilkan sertifikat yang cacat hukum atau adanya sertifikat ganda yang termasuk dalam kategori perbuatan melawan hukum.

\section{Proses Penyelesaian Perbuatan Melawan Hukum dalam Sengketa Tanah Lapangan Bola (Studi Putusan Nomor 17/Pdt.G/2020/PN Kla)}

Pada hakikatnya, kasus pertanahan merupakan benturan kepentingan (conflict of interest) di bidang pertanahan antara perorangan dengan perorangan, perorangan dengan badan hukum, badan hukum dengan badan hukum dan lain sebagainya. Guna mendapatkan kepastian hukum sebagaimana diamanatkan dalam UUPA, maka terhadap kasus pertanahan dimaksud antara lain dapat diberikan respons ataupun penyelesaian kepada yang berkepentingan (masyarakat dan pemerintah).

Proses penyelesaian sengketa tanah pada umumnya dapat dilakukan melalui forum pengadilan (litigasi), namun demikian bisa juga diselesaikan melalui kerangka pranata alternatif penyelesaian sengketa (Disputes Resolution), seperti melalui misalnya melalui lembaga-lembaga yang berwenang Badan Arbritase Nasional Indonesia (BANI), kemudian melalui Negoisasi, Mediasi, Konsiliasi, Mediasi, selain itu dapat juga melalui Badan Pertanahan Nasional. Beberapa cara penyelesaian sengketa tanah di Idonesia dapat ditempuh melalui beberapa cara berikut ini:

1. Jalur Pengadilan (litigasi)

Litigasi merupakan proses penyelesaian sengketa di pengadilan, di mana semua pihak yang bersengketa saling berhadapan satu sama lain untuk mempertahankan hak-haknya di muka pengadilan. Hasil akhir dari suatu penyelesaian sengketa melalui litigasi adalah putusan yang menyatakan win-lose solution (Amriani, 2012: 16). Prosedur dalam jalur litigasi ini sifatnya lebih formal (very formalistic) dan sangat teknis (very technical). Seperti yang dikatakan J. David Reitzel "there is a long wait for litigants to get trial", jangankan untuk mendapat putusan yang berkekuatan hukum tetap, untuk menyelesaikan pada satu instansi peradilan saja, harus antri menunggu (Harahap, 2009: 233). Prosedur penyelesaian sengketa yang dilaksanakan di pengadilan (litigasi), lazimnya dikenal juga dengan proses persidangan perkara perdata sebagaimana ditentukan berdasarkan hukum acara perdata (HIR).

2. Jalur Penyelesaian Sengketa Alternatif (non-litigasi)

Penyelesaian sengketa melalui non-litigasi jauh lebih efektif dan efisien sebabnya pada masa belakangan ini, berkembangnya berbagai cara penyelesaian sengketa (settlement method) di luar pengadilan seperti:

a. Arbitrase

Pasal 1 ayat (1) Undang-Undang No 30 Tahun 1999 menjelaskan bahwa, "Arbitrase adalah cara penyelesaian suatu sengketa perdata di luar pengadilan umum yang didasarkan pada perjanjian arbitrase yang dibuat secara tertulis oleh paa pihak yang bersengketa". Arbitrase digunakan untuk 
mengantisipasi perselisihan mungkin terjadi maupun yang sedang mengalami perselisihan yang tidak dapat diselesaikan secara negosiasi/konsultasi maupun melalui pihak ketiga serta untuk menghindari penyelesaian sengketa melalui peradilan.

b. Negosiasi

Negosiasi merupakan komunikasi dua arah yang dirancang untuk mencapai kesepakatan pada saat kedua belah pihak memiliki berbagai kepentingan yang sama maupun yang berbeda. Negosiasi ialah proses tawar-menawar untuk mencapai kesepakatan dengan pihak lain melalui proses interaksi, komunikasi yang dinamis dengan tujuan untuk mendapatkan penyelesaian atau jalan keluar dari permasalahan yang sedang dihadapi oleh kedua belah pihak.

c. Mediasi

Menurut Peraturan Mahkamah Agung No 1 Tahun 2016 tentang Prosedur Mediasi di Pengadilan adalah cara penyelesaian sengketa melalui proses perundingan untuk memperoleh kesepakatan para pihak dengan dibantu mediator. Mediasi (mediation) melalui sistem kompromi (compromise) diantara para pihak, sedang pihak ketiga yang bertindak sebagai mediator hanya sebagai penolong (helper) dan fasilitator.

d. Konsiliasi

Konsiliasi merupakan lanjutan dari mediasi. Mediator berubah fungsi menjadi konsiliator. Dalam hal ini konsiliator menjalankan fungsi yang lebih aktif dalam mencari bentuk-bentuk penyelesaian sengketa dan menawarkannya kepada para pihak. Jika para pihak dapat menyetujui, solusi yang dibuat konsiliator akan menjadi resolution.

e. Penilaian Ahli

Penilaian ahli merupakan cara penyelesaian sengketa oleh para pihak dengan meminta pendapat atau penilaian ahli terhadap perselisihan yang sedang terjadi (Nogroho, 2009: 21-22).

Berdasarkan Putusan Nomor 17/Pdt.G/2020/PN Kla menyatakan bahwa mengabulkan permohonan Penggugat, menyatakan surat gugatan yang telah didaftarkan di Kepaniteraan Pengadilan Negeri Kalianda di bawah register perkara perdata Nomor 17/Pdt.G/2020/PN Kla tanggal 23 Maret 2020 telah dicabut, memerintahkan gugatan Penggugat dalam perkara perdata Nomor 17/Pdt.G/2020/PN Kla dicoret dari register perkara perdata gugatan serta membebankan biaya perkara ini kepada Penggugat yang sampai saat ini ditaksir sejumlah Rp.1.490.000,00 (satu juta empat ratus Sembilan puluh ribu rupiah).

Penyelesaian sengketa hak atas tanah antara pihak penggugat dan pihak tergugat di Pengadilan Negeri Kalianda dengan Nomor Perkara 17/Pdt.G/2020/PN Kla dengan metode penyelesaian sengketa secara litigasi sudah tepat dilakukan 
karena proses penyelesaian melalui mediasi yang telah dilakukan oleh kedua belah pihak tidak menemui titik terang karena Hakim dalam menjatuhkan putusan di atas sudahlah tepat dan berpedoman dengan peraturan perundang-undangan yang mengatur tentang hak milik atas tanah. Hal ini dapat dilihat bahwa hakim berpedoman dengan alat-alat bukti yang telah diajukan oleh kedua belah pihak baik itu alat bukti surat dan keterangan saksi yang telah diperiksa dalam persidangan.

Hasil wawancara dengan Chandra Revolisa selaku Hakim Pengadilan Negeri Kalianda menyatakan bahwa hakim menilai dengan pertimbangan-pertimbangan hukumnya bahwa dalil-dali yang diajukan ataupun didalilkan oleh pihak Penggugat dalam proses selama persidangan dapat dibuktikan kebenarannya dan berkekuatan hukum. Perjanjian Ganti rugi yang diajukan oleh Pihak Penggugat sebagai bukti surat merupakan alat bukti yang sah yang dimana menurut Pasal 1320 KUH Perdata, suatu perjanjian adalah sah apabila memenuhi persyaratan sebagai berikut yaitu: kesepakatan antara para pihak, cakap hukum, sebab sesuatu hal tertentu dan suatu sebab yang halal. Keempat unsur tersebut sudah terpenuhi didalam perjanjian ganti rugi yang diajukian oleh pihak Penggugat.

Hasil wawancara dengan Eka Maisanti selaku Panitera Pengadilan Negeri Kalianda menyatakan bahwa permasalahan dalam perkara ini sebenarnya lebih mengarah kepada adanya dua alas hak atas tanah atau lebih dikenal dengan sebutan sertifikat ganda. Pihak Tergugat yang mengaku memiliki hak atas tanah merupakan suatu perbuatan melawan hukum yang dapat merugikan pihak Penggugat.

Berdasarkan analisis tersebutlah maka putusan pengadilan atas perkara ini sudahlah tepat dan adil sehingga pihak Penggugat tidak merasa hak-haknya tidak diambil orang dan mendapat keadilan. Proses penyelesaian perbuatan melawan hukum dalam sengketa tanah lapangan bola di Dusun Jatisari Desa Jatimulyo Kecamatan Jati Agung Kabupaten Lampung Selatan berdasarkan Putusan Nomor 17/Pdt.G/2020/PN Kla adalah dengan metode penyelesaian sengketa secara litigasi, dimana litigasi merupakan proses penyelesaian sengketa di pengadilan, di mana semua pihak yang bersengketa saling berhadapan satu sama lain untuk mempertahankan hak-haknya di muka pengadilan.

\section{PENUTUP}

Berdasarkan hasil penelitian maka, dapat diambil kesimpulan sebagai berikut: Pertama, Faktor penyebab terjadinya perbuatan melawan hukum dalam sengketa tanah lapangan bola di Dusun Jatisari Desa Jatimulyo Kecamatan Jati Agung Kabupaten Lampung Selatan berdasarkan Putusan Nomor 17/Pdt.G/2020/PN Kla adalah karena adanya kelalaian (culpa) atau karena kesengajaan (dolus) yang dilakukan Kecamatan Jati Agung dalam pembuatan surat tidak dalam sengketa atas tanah objek perkara sehingga Pihak Tergugat mendaftarkan tanah objek perkara ke kantor Badan Pertanahan Kabupaten Lampung Selatan. Oleh karena perbuatan 
karena kelalaian atau kesengajaan akan menghasilkan sertifikat yang cacat hukum. Oleh karena perbuatan karena kelalaian atau kesengajaan akan menghasilkan sertifikat yang cacat hukum atau adanya sertifikat ganda yang termasuk dalam kategori perbuatan melawan hukum.

Kedua, Proses penyelesaian perbuatan melawan hukum dalam sengketa tanah lapangan bola di Dusun Jatisari Desa Jatimulyo Kecamatan Jati Agung Kabupaten Lampung Selatan berdasarkan Putusan Nomor 17/Pdt.G/2020/PN Kla adalah dengan metode penyelesaian sengketa secara litigasi, dimana litigasi merupakan proses penyelesaian sengketa di pengadilan, di mana semua pihak yang bersengketa saling berhadapan satu sama lain untuk mempertahankan hak-haknya di muka pengadilan.

Berdasarkan kesimpulan di atas, maka dapat diberikan saran antara lain: Pertama, kepada masyarakat hendaknya lebih memahami lagi bagaimana hak-hak atas tanah menurut hukum yang berlaku di Indonesia. Hal ini sangatlah penting mengingat banyaknya permasalahan hak atas tanah yang sering terjadi akibat dari bebrbagi jenis permasalahan yang faktor utamanya dikarenakan ketidaktahuan masyarakat tentang pengaturan hak atas tanah. Hendaknya masyarakat ketika akan melakukan pengalihan hak atas tanahnya sekaligus juga melakukan pendaftaran pengalihan haknya pada Kantor Pertanahan.

Kedua, kepada Badan Pertanahan Nasional hendaknya lebih hati-hati lagi dalam proses menerbitkan sertifikat hak atas tanah. Hal ini sangatlah penting karena besarnya kemungkinan adanya surat-surat palsu mengenai keterangan hak atas tanah yang diterbitkan oleh oknum-oknum pejabat tata usaha negara untuk kepentingan pihak-pihak tertentu agar dapat memiliki hak atas tanah.

\section{DAFTAR PUSTAKA}

Abdul Kadir Muhammad. 2000. Hukum Perdata Indonesia. Citra Aditya Bakti, Bandung.

Herlien Budiono. 2010. Ajaran Umum Perjanjian dan Penerapan di Bidang Kenotariatan. Citra Aditya, Bandung.

Mirriam Budiardjo. 2009. Dasar-dasar Ilmu Politik. Gramedia Pustaka, Jakarta.

Nurnaningsih Amriani. 2012. Mediasi Alternatif Penyelesaian Sengketa di Pengadilan. Grafindo Persada. Jakarta.

Susanti Adi Nugroho. 2009. Hukum Persaingan Usaha di Indonesia. Prenada Media, Jakarta. 
Tami Rusli. 2012. Hukum Perjanjian yang Berkembang di Indonesia, Anugrah Utama Raharja (AURA) Printing \& Publishing, Bandar Lampung.

Yahya Harahap. 2009. Hukum Acara Perdata Tentang Gugatan, Persidangan, Penyitaan, Pembuktian, dan Putusan Pengadilan. Sinar Grafika, Jakarta. 